Jusmal llmial

PEUR AA DE

Vol. 5, No. 2, May 2017

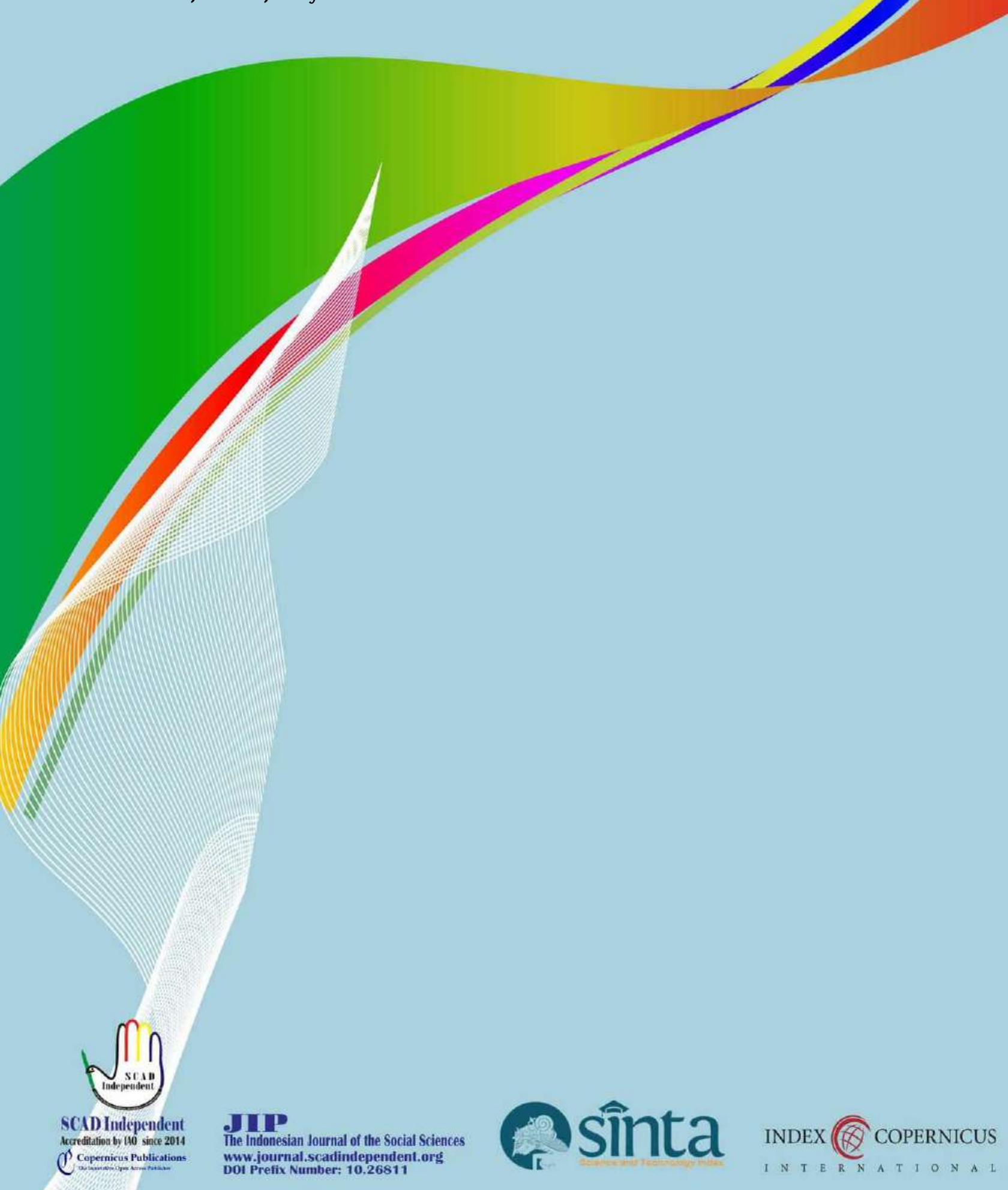




\title{
THE IDEAS AND CONCEPTS OF OVERTURE MUSIC COMPOSITION: \\ One of the Opera Music Compositions of Kehidupan Dua Zaman Hikayat Siboru Deakparujar on the Creation of New Mode and Rhythm of Ogung Instrument
}

\author{
Junita Batubara \\ University of Education of Sultan Idris, Malaysia \\ Contibutor Email: nitabtbara72@gmail.com
}

Received: April 30, 2017

Accepted: May 21, 2017

Published: May 27, 2017

Article Url: http://journal.scadindependent.org/index.php/jipeuradeun/article/view/149

\begin{abstract}
The main problem in the composition idea of Overture is the studying of Opera itself but very few works of opera compositions that combine Western music with the traditional music of the Batak Toba Indonesia. Second, in the traditional opera of Batak Toba, it is often performed musical themes taken from the social life story of Batak Toba society and it is extremely rare, especially among the people of Batak Toba. Third, in the Batak opera, the music is used only as an entertainment and separated from the content of the story and often does not have the music score. The Overture created uses Atonality scale inspired by the pentatonic music of Batak Toba by using music score. Fourth, collecting information related to the influence of Western music, in this case, Atonality and pentatonic music of Batak Toba. Fifth, The use of the musical elements such as melody, rhythm pattern, tone color, harmony, form, texture and orchestra. With the above description, the writer created an opera based on the employment elements of Western music and Batak Toba music. The author made the employment of methods with the use of a rhythmic pattern on traditional musical instruments ogung and sulim combined with Western musical instrument without changing each ton of each musical instrument of the traditional Batak Toba. Sixth, the mode of pentatonic (five pitch) in which five pitch is the texture of taganing mode in the ensemble of gondang hasapi (an ensemble of the traditional music of the Batak Toba, North Sumatra in Indonesia) that are customized according to the tuning system of twelve of Western music pitch in order to generate new modes used in the above employment of opera.
\end{abstract}

Keywords: Music Composition, Atonality Scale, Modus/Mode, Music Instruments Influence 


\section{A. Introduction}

Batak opera is a traditional opera theater that is coming from around the City of Batak Toba in Indonesia. This opera was created by Tilhang Gultom around 1920 (Johnson, 2005: 64). The function of this Batak opera is as a means of culture expression that shows the traditional opera works of Batak Toba City. Normally opera Batak took the story of the problems emerging in society of the city itself. Nowadays very rare performances of opera Batak due to several factors such as the occurrence of a change in the elements of culture, lack of works of opera and also the lack of opera composers who created the work in Indonesia, particularly in the City of Batak Toba. And Batak opera is often performed orally so the documentation in the form of a script and musical score are rarely found.

This study is an investigation of the process of producing an opera entitled Kehidupan Dua Zaman-Hikayat Siboru Deakparujar where one part of the opera discussed in this study is part of Overture. This opera is inspired by the folklore of the town of Batak Toba Siboru Deakparujar. Opera was created and formed by the influence of elements of Western music with traditional music that is Atonality with the music of Batak Toba. The influence is hoped will be one alternative to preserve and help to preserve traditional of arts performance of opera Batak by using a new and different approach.

\section{B. The Definition of Opera in Brief}

Opera comes from the Italian opera in musica or work in music. This definition is used when all the actors sing the dialogue as a whole or in part for a performance of a play presented by the music (Prier, 1996: 143). According to Kennedy (2007: 546) Opera (within the meaning of works, but actually the plural of Latin opus or work, the Opéra in French and German is Oper). Opera is a drama that is available for music, sung with musical instruments, casted by the singer using a variety of clothes that are tailored to the plot, the dialogue or speech-like recitative. The essence of the opera is that the music is very important and has a structure uniformly. Steib (1999: 387) also stated that in an opera usually music is always linked to the singing. This singing formed of a storyline called a 
libretto. The word libretto comes from Italian means "little book" and every libretto is different from the synopsis or storyline of the scenario.

Wilson (2010: X) has a different opinion which he stated that, opera is an art form that combines text, music, visual presentation and movement, lends itself particularly well to the discipline, context and cultural approach. The review of opera is now learned by the approach taken from other fields such as sociology, gender studies, psychoanalysis and medication. Based on the above explanation, it can be concluded that the structure of Western opera includes dialogue, narration, acting, singing, formed from the story or the libretto where the context comes from the social, cultural, political and ideological use of music instruments which serves as a 'starter'1 interlude and as an accompaniment rather than acting.

\section{The Composers Conducting Cross-Cultural Works in composition}

Many composers employ cross-cultural approach in creating a musical composition in terms of distribution as written by Western composers, or in terms of resistance to Western hegemony ${ }^{2}$ and written by an East Asia composer (Cook, 2009: 3). While Waridi (2006: 71-75) argues that there are two important things in distinguishing between the traditional approach and modern approaches/ Western music, especially in the area of the creation of music, the fact that traditional approaches create works of art by using traditional idioms like: form, technique/ design, cengkok/ twisted ${ }^{3}$ and so on. This idiom is more to enrich the repertoire that already exist, whereas modern/ Western music creates work that seeks to free itself from all the conventional rules that apply to the music genre, game instruments and the other conventional, so that in

\footnotetext{
${ }^{1}$ Starter means music instrumental as the initial introduction of an opera, often called as an overture without acting and singing

${ }^{2}$ Hegemony is associated with the relationship between a particular class of society in which the dominant unit will monopolize the other unit in terms of economic, cultural and moral. Western hegemony meant Western influence. The Western perspective sees that Eastern culture is always seen as a division, as music is borrowed to represent or characterize Eastern music. In retaliation, the Eastern cultural perspective practices various forms of cultural opposition to Western influences, such as incorporating Eastern ideas into Western art music.

${ }^{3}$ Cengkok is a form of ornamental tone that awakens the verses of the song.
} 
this group creators are given freedom in processing and interpreting their works without having to be burdened with the rules of tradition.

Based on the opinions above, the authors try to make a statement that the composers approach sounds and find new ideas to create a piece of new music with new resources. Sources of inspiration can be found through folk music, popular music or influences of other composers from both countries in the East or the West; each section has special different features. In this case the writer took the sample of some music composer's who merge Eastern and Western music, especially from Indonesia, both in terms of ideas and musical instruments.

Godet (1978: 113) in his "En Marge de la Marge" in La Revue Musicale and Hugh (1997: 1) in his writing Claude Debussy and the Javanese Gamelan have said the same thing that, Claude Debussy, a young composer, deeply affected with the dance and Javanese gamelan presented in 1889 at the Paris Universal exhibition ${ }^{4}$. In the exhibition, groups from all over the world came together and gave their best performances of art and music branches, culture and lifestyle of their country. It is also supported by Karpati (1964: 181), where knowledge of music and dance that attracted worldwide attention associated with the works of Debussy's music after he heard and saw the gamelan music of Indonesia at the Universal Exposition in Paris in 1889. Music and dance have a very profound impact on Debussy so he wanted to adapt and apply back into the sound of Western musical instruments using the pentatonic scale of the ensemble.

Debussy piano's work titled Pagodes of Estampes is clearly influenced by gamelan music. In this work Debussy has used elements of dance music as the inspiration of the scale sléndro melody, timbre of musical performances and dance, and rhythm elements of the game with staccato gong. The texture is continuously performing the various ensemble instruments such as the rhythm of 3 to 2 (Hugh 1997: 7).

4 see Johnson, Henry (2008: 61). Composing Asia in New Zealand: Gamelan and Creativity. 


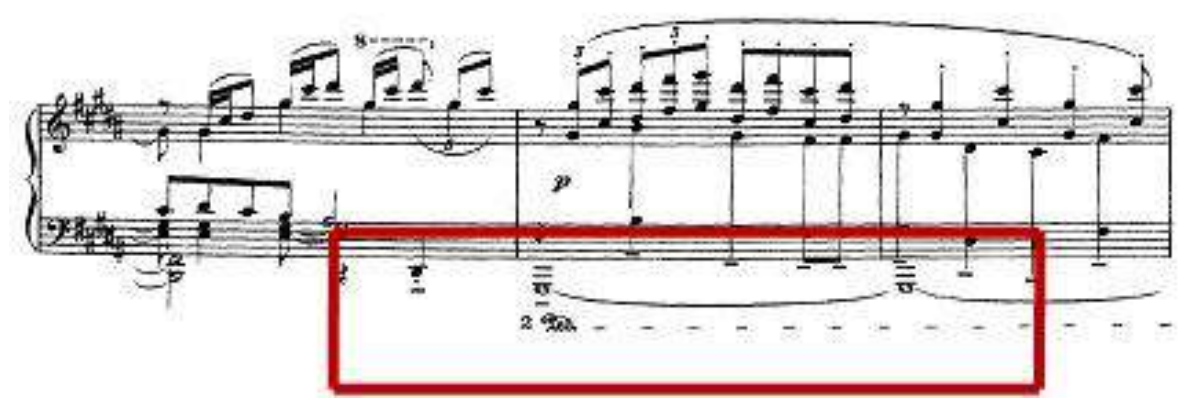

Music score sample 1.1 Pagodes Music for piano using the pentatonic scale B C \# D \# F G \# from bar 11 and bar 12

According to Dieter Mack (2009: 126), in the late 1920s McPhee could hear various the recording of Balinese musical (recording of Odeon Company in 1928). The concept of music rhythm of Bali has much in common with the Javanese gamelan, so it is not surprising if McPhee is very interested in the subtleties of the music and artistry. The peak of the influence of Bali on McPhee's work can be seen through the orchestral percussion. The orchestra can be seen as a tribute to the music of West Bali by a composer who had 'fallen in love' with Balinese culture itself. McPhee was able to create this work not only to imitate the style of Balinese gamelan but also with various instruments collection of original music from Bali (Dieter, 2009: 127).

The writer also had the opportunity to hear the work of Colin McPhee, entitled percussion Performed by Twilite Orchestra of Indonesia led by Addie MS on July 21, 2009 in the concert hall of the Opera House, Sydney. In this work McPhee use sléndro scale of the Balinese gamelan. On the whole, this presentation uses the melody of Balinese gamelan. Melodies and rhythms of Balinese gamelan on musical instruments piccolo and flutes 1 and 2, piano 1 and 2 play chords, ceng-ceng (traditional musical instruments of Bali) resembles the small cymbals and are played with both hands (video, 2010), clarinet melody was as a carrier melody variations replacing bamboo flute; the music instrument from Bali, bass clarinet, bassoon, horn and bass Basson (four) as drones (see music score sample 1.3). 


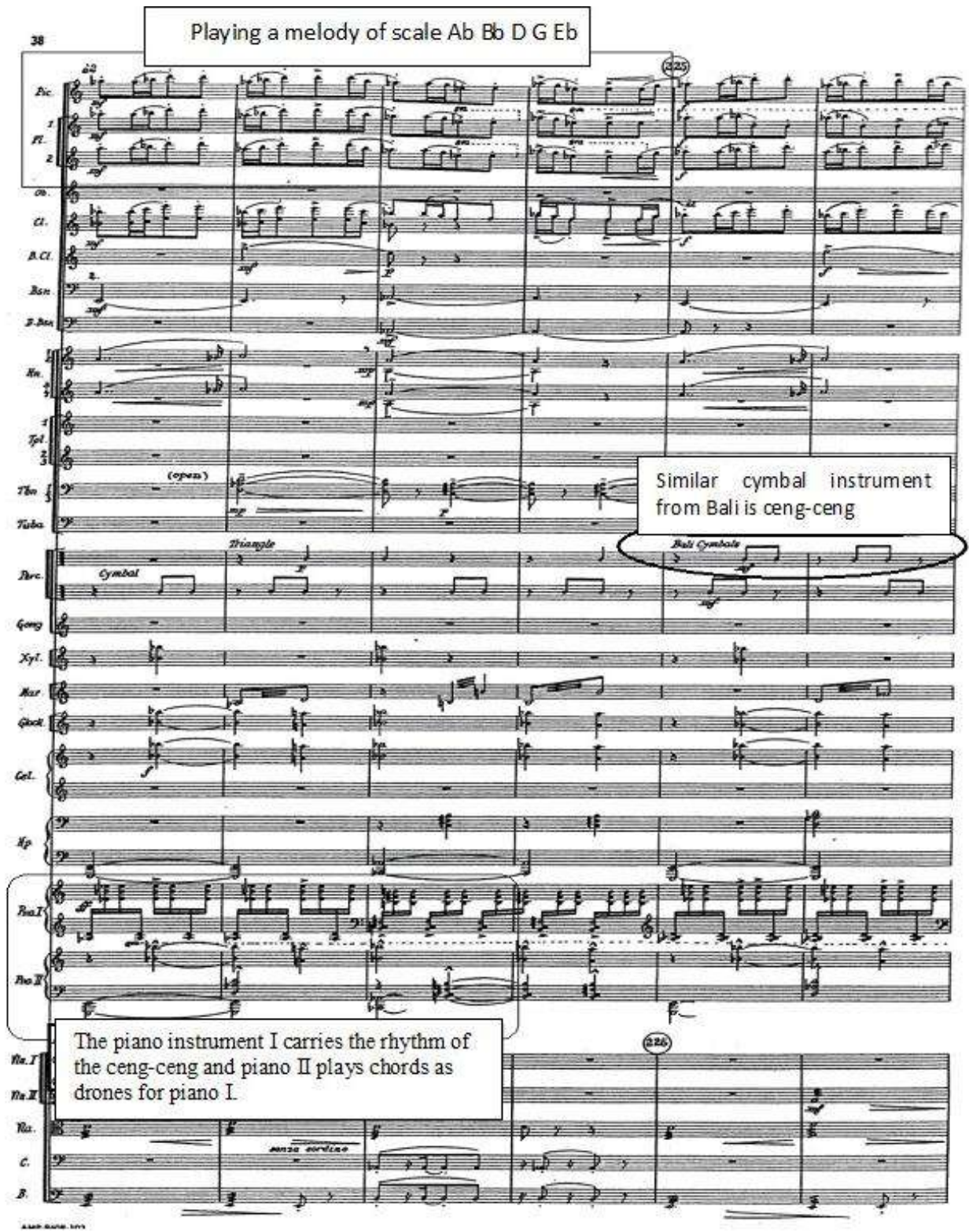

Music score sample 1.2 of Music percussion for two pianos and orchestra

Johnson (2008: 61-62) conducted research about the composer from New Zealand who got the influence of the Indonesian gamelan music, they were Jack Body and Gareth Farr. Body was known to have relation to dance; especially he was as a manager of the ensemble group of Victoria 
University in New Zealand. Body's works not only reflect the effects of Indonesian gamelan music but also includes Asia broadly.

In 1974 he came to Indonesia, Yogyakarta to settle for four months. He returned to Indonesia and lived for two years from 1976 to serve as an instructor at the Academy of Indonesia Music in Yogyakarta. Body emphasized the use of dance as an educational tool. He has a composition student at the university who uses instruments to explore new sounds, music structure, and performance practices. Body created music for electro-acoustic, entitled Musik dari Jalan in 1975, Turtle Time (1968). In both compositions, there could be seen Body's ability in his involvement with organ ensemble instrument through the game. Body is a pioneer in the use of music as a technical score composed for the musical score of gamelan instruments and musical scores of Western instruments. This has been used when he is not able to focus on the original compositions ${ }^{5}$. Writing ensemble music score is called a "double transcription". At first, he took a new "need"6 and often alienating the existing (a phenomenon often based on their own field recordings), and then translate the "need" to be played by the West musician.

Meanwhile composer who created the music of the masterpiece of Indonesia opera is Tony Prabowo. Tony Prabowo is one of Indonesia's most famous composers nowadays for his regular performances in Jakarta. He was the first composer in Indonesia which stages contemporary opera called The King's Witch in 2006. In this work, featuring Goenawan Mohamad's poetry called Pastoral to the quartet music for strings and two soprano Ubiet and Binu D. Sukaman.

He also created the opera entitled Kali based on the poetry of Goenawan Mohamad. Ubiet as a singer has a distinctive vocal ornaments of various traditional music of Indonesia. This work was revised several times before it was performed in 2007. In the Kali, Tony uses a blend of vocal style

\footnotetext{
${ }^{5}$ Musical scores for gamelan instruments are rarely encountered due to lack of knowledge of composers or music players to write down their compositions. Jack Body performs the process of writing a musical score for a musical instrument gamelan by writing the traditional musical way (usually to declare pitches with the number) then rewrote it in Western thought.

6 "Needs" in the sense of the source of new sounds of the gamelan music instrument (the chatting through email on May 13, 2011).
} 
ornate with a viola that use a lot of long tones as drones. The Rebab Minang is one idea for the 'timbre' technique of string quartet musical instruments such as the technique of sul ponticello (bow played near the bridge).

In 2010, Tony Prabowo also created an opera based on a poem from Goenawan Mohamad entitled Tan Malaka. This work represents a conventional opera with multimedia presentations and more prominent use of the theater. In the opera, Tony Prabowo uses of serialism system by borrowing the sounds and rhythms of the Javanese gamelan, polimeter that add $1 / 2$ on each metronome like $3 / 4(1 / 2), 5 / 4$ (1/2) and so on. In his work, Tony uses more ideas of the traditional music instruments' sounds that are channeled into Western musical instrument ${ }^{7}$.

\section{Method of Creation}

With some examples of the work of the composer's music compositions that do well by doing cross-cultural influence or take an idea, the writer has her own way of doing the creation of Overture music. According to the dictionary of music (2009: 13), Atonality is music without a tonal center or atonal music set. In the twentieth century, some composers developed an approach to composition through a system of new music without a tonal center. Next by Forte (1973) in a book entitled The Structure of Atonal Music as a summary and Kotska (2006: 176) said that there are some features of atonal music set apart from tonal style, that has no tonal center:

1. This aspect is subjective, for any two listeners, may differ on the extent to which the audible tonal center in a particular musical work; however, many other types can be widely accepted without the tonal or atonal.

2. The situation without the tone set can be achieved by avoiding the conventional pattern of harmony and melodic rhythms that help to create a tonality in music that uses traditional tonal music.

3. There are unresolved dissonant, the number of chords mixed-hose is greater, and the materials derived from the chromatic scale.

\footnotetext{
${ }^{7}$ Full information about the Opera Composers from Indonesia Inspired by Western Music Overview that was obtained through a live meeting with Tony Prabowo on November 24, 2010 at Komunitas Salihara, Jakarta.
} 
4. The texture is often contrapuntal, with a theme or melody in the sense of traditional tonal music that is less likely to occur, and metrics organizations often difficult to be understood by the listeners.

With the advent of atonal music features mentioned above, the writer in this opera conducts an experiment; with the use of melody based on some kind of mode system that is pentatonic which consists of five tones and then six, seven and nine tones. Modes are arranged in a variety of different interval. One of pentatonic scale chosen by the writer is the application of texture of musical instruments mod of taganing of Gondang hasapi ${ }^{8}$ ensemble, where an application has been made by Irwansyah Harahap (2005: 50) as indicated below where the laying of a number corresponding to the order of its tone:

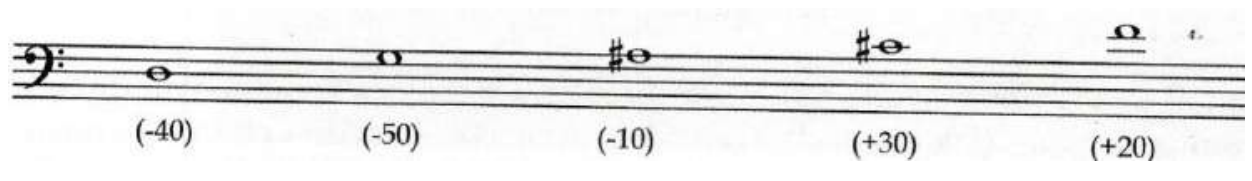

Music score sample 1.3 Music mode and adjustment from Taganing of Gondang Hasapi Musical instruments

Apart from the pentatonic, the writer made her own mode creation consisting of five, six, seven and nine peach along with a free mode. Then, the writer studied the mode concept of five, six, seven and nine pitches that were transposed twelve times by the tuning system of western music. In the work of Overture, the writer used mode five by naming it Mode G. The use of the alphabet was only to name the mode. G Mod was inspired by Taganing, Gondang Hasapi (see the music score sample of music 1.3). Mod G scale consists of five pic / ringing initiated from B, C, D, D \#, E a distance of semitones, two semitones, one of semitones and semitones. After the formation of scale five-pic/ tune based on a predetermined semitone, next

\footnotetext{
in Indonesia.

${ }^{8}$ Gondang hasapi is one of the traditional musical ensembles of Batak Toba-North Sumatra
} 
the writer changed the order of twelve times by the tuning system of western music with the same distance as the previous semitones. After changing the order, then there were scales of pitch five with different tonal center. Next, the scales were used to form chords that were more than two pitches/ tunes that were stacked vertically with an interval of one, two and three.

By changing the order, there were various modes with different tonal center. The aim is to produce new modes used in the work of the opera as described above. Besides, the writer also maintained the pitches of traditional musical instruments until they were merged with traditional musical instruments of Batak Toba and western music that produced distinctive 'timbre'9. Thus the writer who has a background of Western music studied the creation of an opera based on the incorporation of Western music and traditional music namely Atonality and Batak Toba.

\section{E. Overture as Pre-Show in Opera}

In the opera, Overture is a pre show offering in the form of a combined instrument orchestra of Western music and traditional music of Batak Toba. The Overture arrangement is A and B, there is no repetition. Part A is started from the bar 1 to bar 48 and the B started from bar 49 to bar 116. The use of mode $G$ in Overture as a single mode is on trial with the use of a pause mode and selection of different chords produced in accordance with the selected mode, below the writer describes the use of modes and G chord at Overture.

\section{Mode $G$ started at pic $B$ tonal center}

Mode G started in tonal center pitch / tone B of the pitch / tone B, $C, D, D$ \#, E is found on the bar 3 flutes beat 3 to beat 5 . It can be seen in the music score sample music image below:

9 The term 'timbre' means every Western musical instrument as well as the traditional musical instruments used by the writers in the opera mentioned above have distinctive features of different sounds. When both types of instruments are played together or play the same pitches then the sound produced is a combination of the sound of both instruments. 


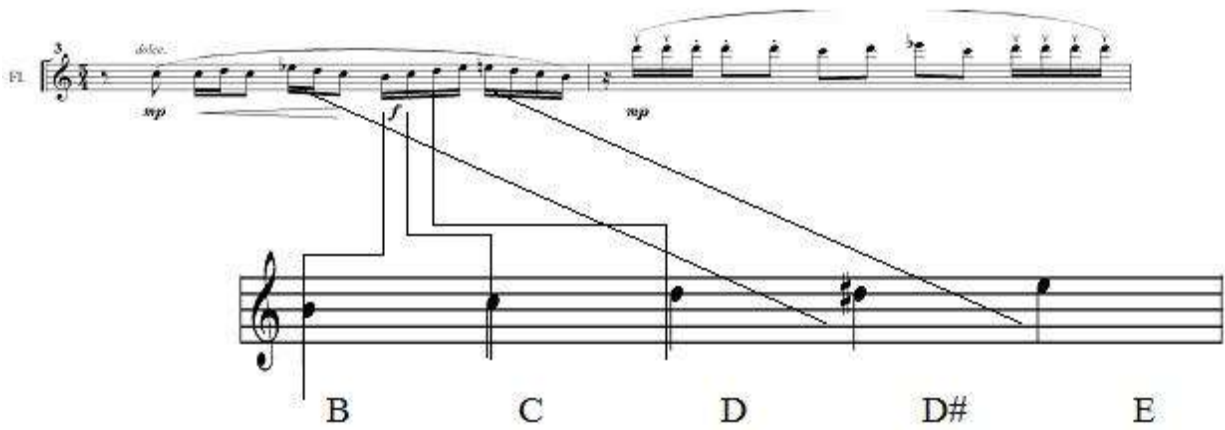

Music score sample 1.3 Mod G started at Pic B tonal center on flut

\section{G chord Mode started At pic tonal center of B and G}

There is a $G$ chord mode started in tonal center pitch $B$ as the basis for the $G$ chord mode on bar 5 and 6 . At the bar 5 beats 1 , there is tonal center pitch $B$ that has two intervals which consists of 3 pic. Later on bar 5 beats 2 to bar 6 , there is tonal center of pitch B that has two intervals consists of 4 pic. At the bar 8 there is Mode G started in tonal center of pitch $G$ and $G$ chord mode which consists of 3 pic initiated in tonal center pitch $G$ interval. The selection of chords based on $G$ mode with one and two interval. In this section the writer wanted to show the difference tones as a sound effect that is produced from the chords. The chords supported the atmosphere desired by the writer. This can be seen in the music score sample of music image below:

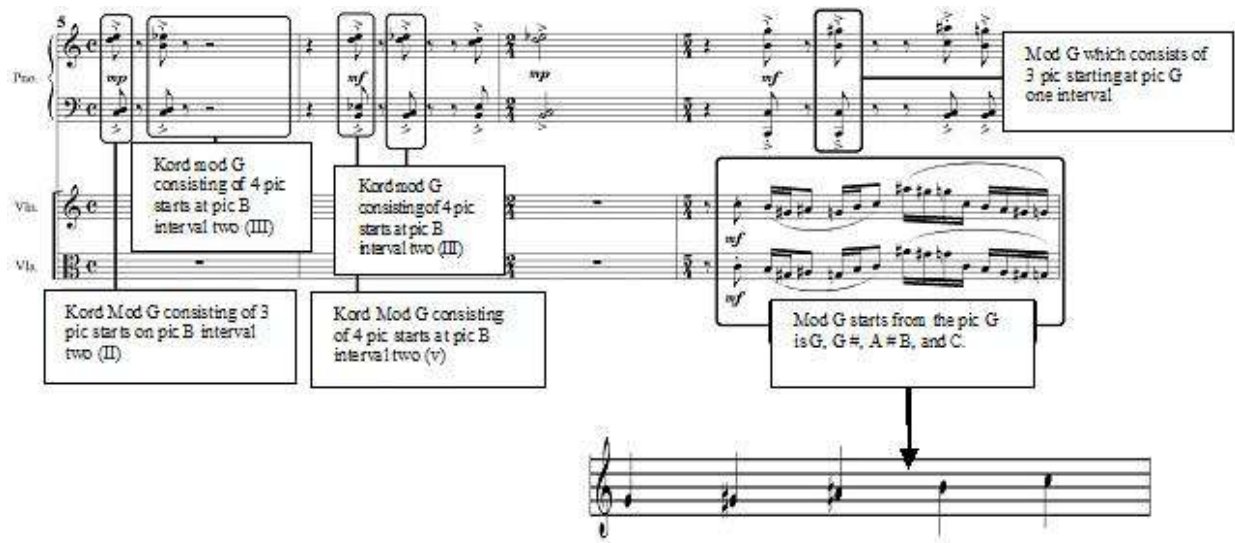

Music score samples 1.4 G Chord Mode initiated in tonal center of Pic B and G 


\section{Mode G Initiated At the tonal centers of Pic G and Pic A}

There is Mode $\mathrm{G}$ which started in the tonal center of pic $\mathrm{G}$ namely $\mathrm{G}, \mathrm{G}$ \#, A \#, B, C on the violin and viola in bar 9 beat 1 to beat 4 . Then, there is a tonal center of pic $\mathrm{A}$, called $\mathrm{A}, \mathrm{Bb}, \mathrm{C}, \mathrm{C} \#, \mathrm{D}$ in bar 10 beat 1 to bar beat 3 . It can be seen in the music score sample of the music image below:

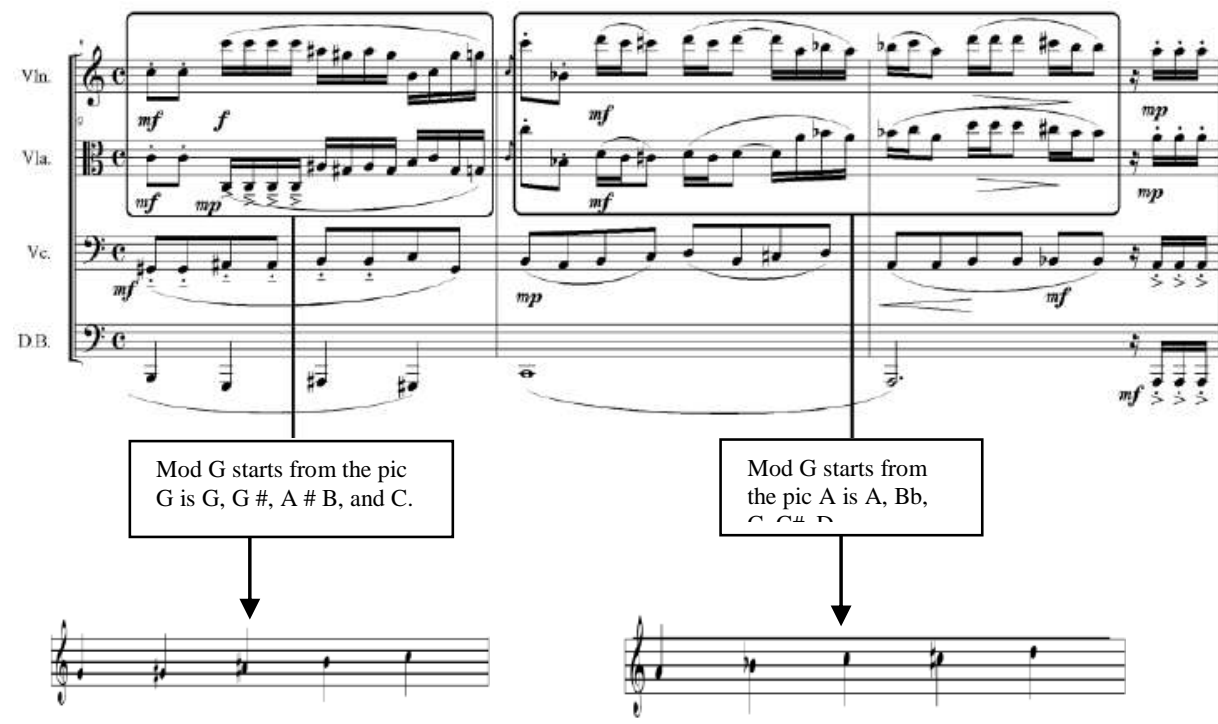

Music score samples 1.5 G mode started in tonal center Pic G and Pic A on violin and viola

\section{Mode G Started At pic D tonal center}

There is Mode G started in tonal center, those are D of D, Eb (D \#), $\mathrm{F}, \mathrm{F} \#, \mathrm{G}$ on the violin in bar 30. It can be seen in the music score sample of music image below:

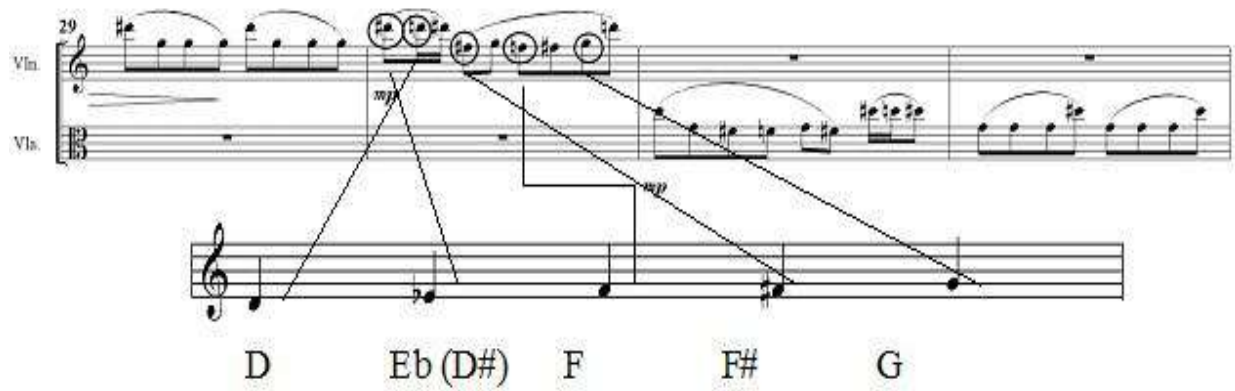

Music Sample 1.6 Mod G which started at Pic D tonal center on violin and viola 


\section{Mode $\mathrm{G}$ started At pic $\mathbf{F}$ tonal center}

There is Mode $G$ which started in the tonal pitch F, those are F, F \#, $\mathrm{G}$ \#, A, Bb / A \# on the oboe instrument in bar 37 to bar 39 beat 2. It can be seen in the music score sample of music image below:

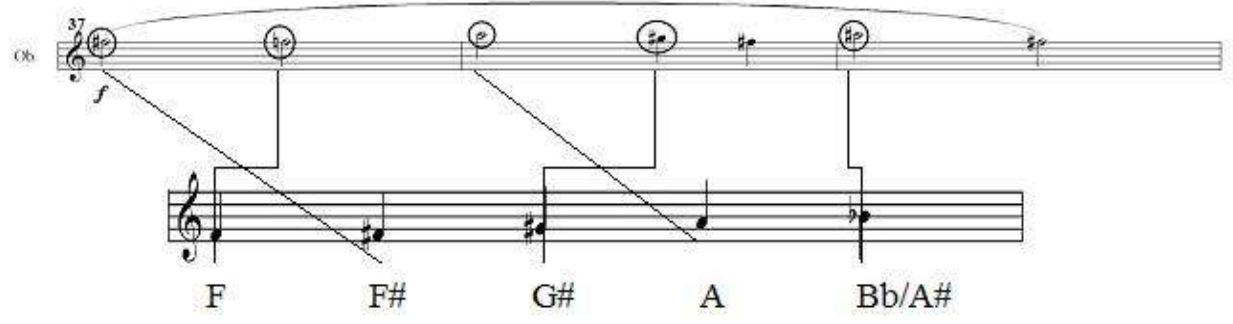

Music Sample 1.7 Mod G which started in Pic F tonal center on obor

\section{F. Melody Pattern At Sulim and String Quartet}

The influence of Western musical instruments and traditional music of Batak Toba started in the bar 68 to bar 88 . At the bar 69 to 76 , the melody pattern of musical instruments of sulim and sarune Hetek and also on musical instruments violin, viola and cello played recitative. The Pitches contained in Sulim and sarune Hetek closely resembles the diatonic pitches of Western music. This can be seen in the music score sample of the music below:

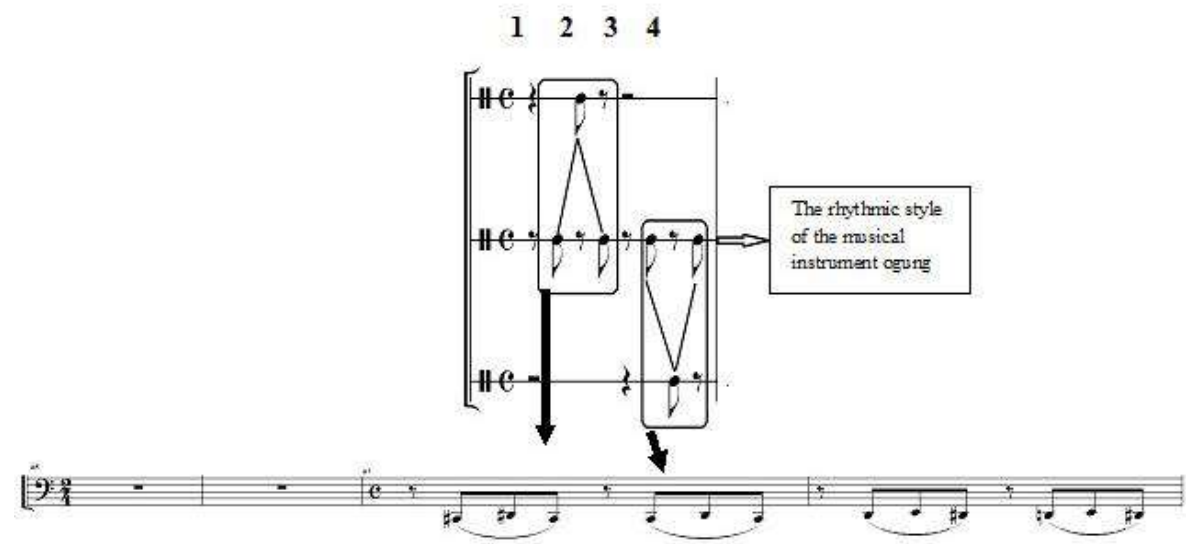

Music score sample 1.8 music rhythm patterns on kontrabes

In Overture the influence of Western music with traditional music of the Batak Toba was in bar 35 to bar 43 that played triplet rhythms 
simultaneously on second percussion, kontrabas, gondang and garantung instruments. The second percussion is woodblock that only played rhythms, but the Gondang and garantung played the rhythms melody. On top of that the piano also played chords with different rhythms. This can be seen in the example of image below:

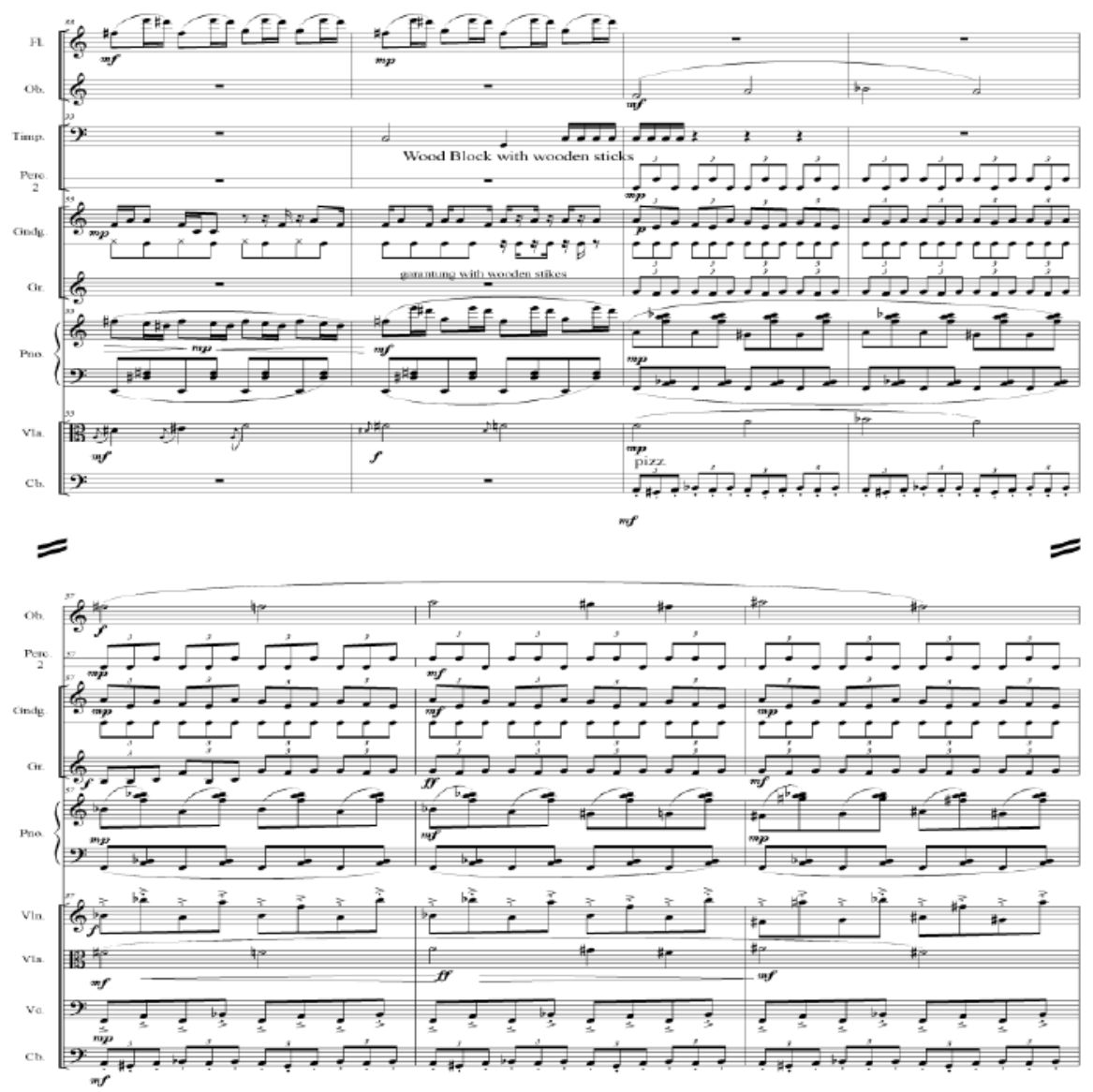

Music Sample 1.9 Full Score of the influence of Western and traditional music instrument of Batak Toba

\section{G. Conclusion}

After going through the process of making an opera, the writer has gathered valuable insight about some concepts of music analogy by doing experiments with various elements of music either about Western music or even traditional Batak music. In a logical and concise conclusion, this Overture music 
composition using one of the pentatonic scales called mode $G$ that was selected by the writer is an application of mode texture of Taganing ensemble musical instruments of Gondang Hasapi of Batak Toba.

The use of these modes in the Overture composition music is one way to produce 'timbre' of each musical instrument used by the writer. Tones Color on traditional musical instruments of Batak Toba have characteristics that are different from the tone color of Western music instruments. For example, Sulim musical instruments has almost the same pitch with flute instrument of Do, Re, Mi, Fa, Sol, La, Ti / Si Do (octave) but the color of the sounds produced are different.

One of the ways the writer used in incorporating elements of Western music with traditional music is to play the melody of both instruments simultaneously, so both of these instruments used the short motif played alternately to complement each other (see music music score sample 1.7 and 1.8). The tones color of Western musical instruments and traditional music were retained. The writer did not make any changes to the tuning of Western musical instruments because of the tones color that were produced by both of these instruments had its own special features. The writer has done a studio recording for the composition of the Overture. After listening to the sounds especially at the Overture, the authors found a 'tone colors' which has never been thought of before, namely the harmonious music that contains additional tons of Batak Toba traditional music. The writer also merged Western music with traditional music by playing the same melody simultaneously. This happened on soprano saxophone, Sulim, sarune Hetek musical instruments that produced the variation of melody. The variations of this melody were taken from a melody of traditional music instrument. There are variations of the melody is played with Western musical instruments.

It should be noted that the initial attraction in the creation of music is the idea that lies in the potential to create the structure of opera associated with musical elements from both the West and traditional Batak Toba. The process of creation the works of Overture composition is also influenced by the way of thinking of the late Ben M. Pasaribu and the late Vincent McDermott to express their ideas into the concept of music 
with different styles. In other words, composers have enough space to carry out artistic intervention into the process of creating their music. This can be seen in the broad perspective to view and create a masterpiece of opera with different styles.

The creation of opera Batak in Indonesia is very rare now. The writer has explained at the beginning. Opera work was created by the writer based on a influence of Western music that is Atonality and Traditional Batak Toba music. The influence is hoping to help preserve one of the Indonesian cultures namely Batak Toba culture. Through this study, it is expected that the work of this opera, could be seen by the people of Indonesia, Batak Toba in North Sumatra as an opera by performing the experiments that combine Western music Atonality and traditional music of Batak Toba. In Batak Toba society there is an opinion that the opera can only be viewed by certain people only. With this in mind, the writer tried to create a work of opera in which this work is considered acceptable in society generally among the young and the elderly.

\section{Bibliography}

Cooks, Lisa M. (2009). Thesis for Ph.D: Living in Northwest Asia: Transcultural and Postwar Art Music. Department of Musicology University of Colorado.

Godet, Robert (1978). 'En Marge de la Marge' in La Revue Musicale. Quoted in Edward Lockspeiser, Debussy:His Life and Mind, Vol I. NY: Cambridge University Press.

Harahap, Irwansyah (2005). Gondang Batak. P4ST UPI. Bandung, Indonesia.

Johnson, Henry (2008). Composing Asia in New Zealand: Gamelan and Creativity. New Zealand Journal of Asian Studies 10. New Zealand

Karapati, J. (1964). Bela Bartok and the East (Contribution to the History of the Influence of Eastern Elements on European Music), Studia Musicologica Academiae Scientiarum Hungaricae, T.6 Fasc.3/4, Akademiai Kiado, 179-194.

Karl E. Prier, SJ. (1996). Ilmu Bentuk Musik. Pusat Liturgi: Yogyakarta.

Kennedy, Michael and Joyce Kennedy (2007), Concise Dictionary of Music. Oxford University Press. New York. 
Kostka, Stefan (2006). Material and Techniques of Twentieth-Century Music (Third edition). Pearson Saddle River. New Jersey 07458.

Mack, Dieter (2009). Sejarah Musik 4. Pusat Liturgi: Yogyakarta.

Muchsin, M. A. (2015). Art and Entertainment in Islam. Jurnal Ilmiah Peuradeun, 3(1), 133-146.

Waridi. (2006). Memaknai Kekaryaan Karawitan: Dari Sudut Pandang Pendekatan Penciptanya. Selonding Jurnal Masyarakat Etnomusikologi Indonesia, Vol. III, No. 1, Jurusan Etnomusikologi ISI Yogyakarta.

Wilson, Alexandra (2010). Opera A Beginner's Guide. One world Publication. New York, NY 10013, USA.

\section{Websites}

Brenthugh. Access at 23 Ogost 2013. brenthugh.com/debnotes/gamelan.html.

History of Opera, History world. Access November 11, 2011. for: Steib $<$ http//www.historyworld.net/wrldhis/PlainTextHistories.asp?h istoryid=ab36> 
p-ISSN: 2338-8617

Vol. 5, No. 2, May 2017 e-ISSN: 2443-2067 